Note

\title{
Application of the long chain diol index (LDI) paleothermometer to the early Pleistocene (MIS 96)
}

\author{
B.D.A. Naafs *, J. Hefter, R. Stein \\ Alfred Wegener Institute for Polar and Marine Research, Department of Marine Geology and Paleontology, D-27568 Bremerhaven, Germany
}

\section{A R T I C L E I N F O}

\section{Article history:}

Received 21 March 2012

Received in revised form 8 May 2012

Accepted 23 May 2012

Available online 1 June 2012

\begin{abstract}
A B S T R A C T
Recently, a new organic geochemical paleothermometer based on the relative abundance of long chain alkyl 1,13- and 1,15-diols, the so-called long chain diol index (LDI), was proposed. Because of its novelty, the proxy has not been reported for sediments older than $43 \mathrm{ka}$. We therefore determined the LDI for 14 sediment samples from the early Pleistocene between 2.49 and 2.41 Ma, comprising Marine Isotope Stage (MIS) 98 to 95, and converted the values to sea surface temperature (SST) estimates to test whether the LDI could be applied or not to the early Quaternary. We show that the long chain diols can be preserved in marine sediments from the early Pleistocene, although at our study site this is limited to periods of increased biomarker accumulation (glacials). Although the results are based on a limited time interval and number of samples, the similarity between LDI-based SST and alkenone-based SST from the same samples suggests that the LDI proxy may have potential for studies covering the entire Quaternary.
\end{abstract}

(C) 2012 Elsevier Ltd. All rights reserved.

\section{Introduction}

During the past two decades proxies such as the alkenonebased $U_{37}^{K^{\prime}}$ index (Prahl and Wakeham, 1987) and more recently $\mathrm{TEX}_{86}$ index (Schouten et al., 2002) have become important tools for determining past sea surface temperatures (SSTs). The advantage of such proxies over classical inorganic proxies based on (calcareous) (nanno)fossils is that the biomarkers are often preserved in marine sediments, are not, for example hampered by carbonate dissolution and can be applied in regions where classical faunal proxies fail. Very recently, a novel paleothermometer was proposed. This new proxy is based on the fractional abundance of the $C_{28}$ 1,13- and the $C_{30}$ 1,13- and 1,15-diols (long chain diol index, LDI) and shows a strong linear correlation $\left(R^{2} 0.969, n=162\right)$ between the LDI for sediment core tops from the oceans and the overlying annual mean SST (Rampen et al., 2012). Although long chain diols are common biomarkers in marine sediments (Morris and Brassell, 1988; Versteegh et al., 1997; Rampen et al., 2012), their source organism(s) is(are) not well defined (Rampen et al., 2012). So far, the $C_{30}$ 1,13- and 1,15-diols have been found in eustigmatophyte algae (e.g. Volkman et al., 1992).

Because of its novelty, the LDI has been reported for only one sedimentary record, spanning the last $43 \mathrm{ka}$ (Rampen et al., 2012). Its potential to derive SST using older marine sediments is therefore unknown, although the $C_{28}$ and $C_{30}$ 1,13-diols and $C_{30}$ 1,15-diols have been found in sediments as old as the early Cenozoic (Yamamoto et al., 1996). Here we use marine sediments cov-

\footnotetext{
* Corresponding author. Tel.: +49 (0)471 48312120; fax: +49 (0)471 48311923.

E-mail address: david.naafs@awi.de (B.D.A. Naafs).
}

ering Marine Isotope Stage (MIS) 96 from Integrated Ocean Drilling Program (IODP) Site U1313 to investigate whether or not this proxy can be applied successfully to the early Pleistocene.

\section{Materials and methods}

In total, 14 sediment samples from the primary splice of IODP Site U1313 covering the period between 2.41 and 2.49 million years (Ma), comprising MIS 98 to 95 , were used. The aim was to cover one complete glacial/interglacial cycle from the early Pleistocene to see whether LDI-based SST corroborates SST variation of the order of $5{ }^{\circ} \mathrm{C}$ suggested by other proxies at the study site (Naafs et al., 2010, 2012). Site U1313 is in the mid-latitude North Atlantic at the upper western flank of the Mid-Atlantic Ridge $\left(41^{\circ} 00^{\prime} \mathrm{N}\right.$; $32^{\circ} 57^{\prime} \mathrm{W}$; $3412 \mathrm{~m}$ water depth). The present annual mean SST is $18.3^{\circ} \mathrm{C}$ (Locarnini et al., 2006). The chronology used for the early Pleistocene is based on tuning of sediment lightness $\left(\mathrm{L}^{*}\right)$ to the global benthic $\delta^{18} \mathrm{O}$ stack (Naafs et al., 2012).

Homogenized freeze-dried sediment $( \pm 6 \mathrm{~g}$ ) was extracted using $\mathrm{CH}_{2} \mathrm{Cl}_{2}$ and automated solvent extraction (DIONEX ASE 200; $5 \mathrm{~min}$, $100{ }^{\circ} \mathrm{C}, 1000 \mathrm{psi}$ ). The extract was derivatized with N,O-bis(trimethylsilyl)trifluoroacetamide and $1 \%$ trimethylchlorosilane (BSTFA/TMCS, $200 \mu \mathrm{l}, 2 \mathrm{~h}, 60^{\circ} \mathrm{C}$ ) shortly before analysis using gas chromatography-time of flight mass spectrometry (GC-TOF-MS) using conditions described by Hefter (2008). The fractional abundances of diols were determined using characteristic fragment ions (Versteegh et al., 1997): $m / z 299$ ( $C_{28: 0} 1,14$-diol), 313 ( $C_{28: 0} 1,13-$ and $C_{30: 0} 1,15$-diols), 327 ( $C_{28: 0} 1,12-, C_{30: 1}$ and $C_{30: 0} 1,14$-diols $)$ and $341\left(C_{30: 0} 1,13-d i o l\right)$. In addition to the $\mathrm{LDI}$, the total relative abundances of the $C_{28}$ and $C_{30}$ 1,13-diols and $C_{30}$ 1,15-diols were 


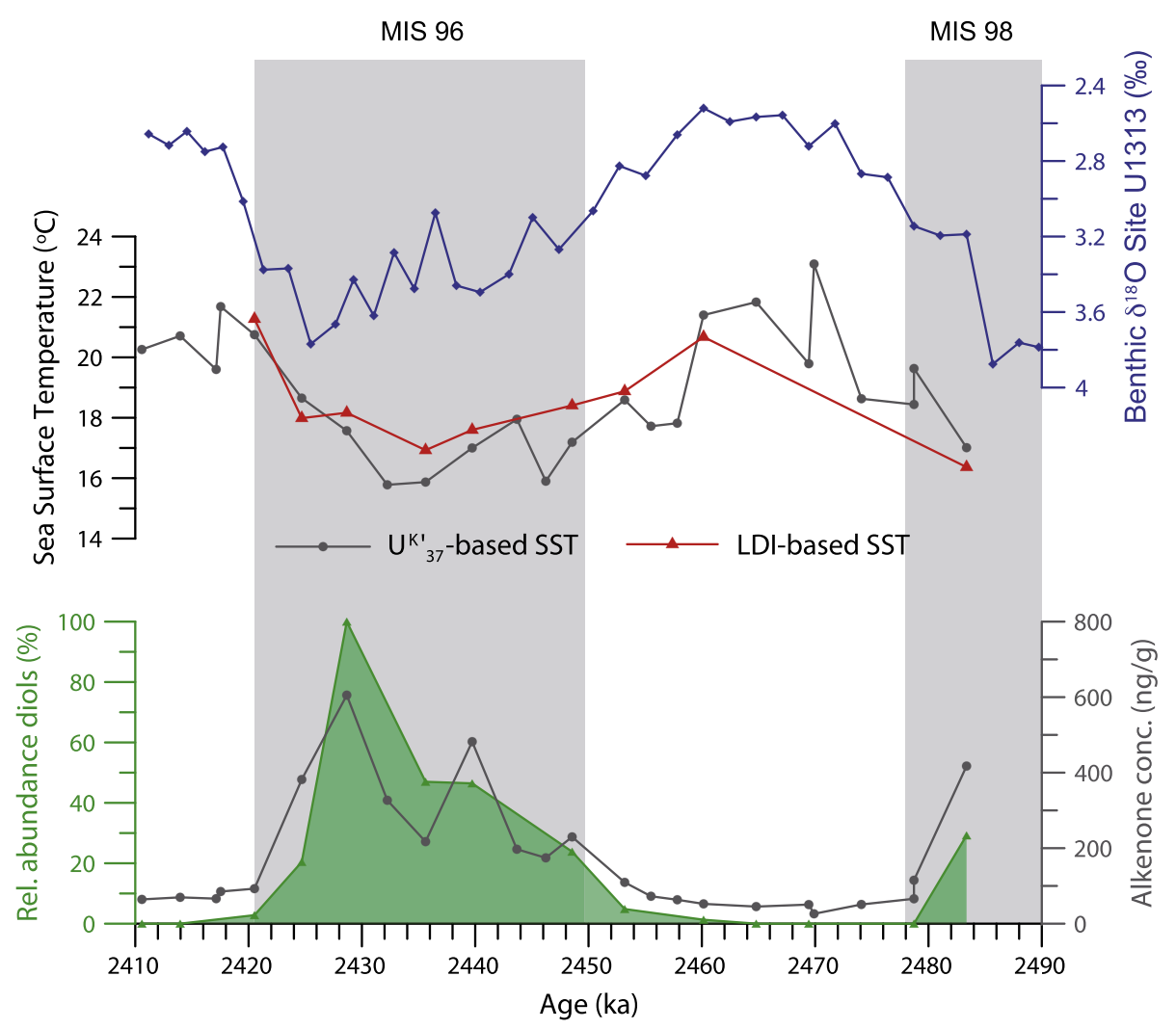

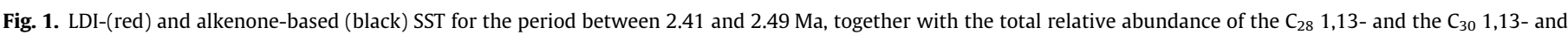

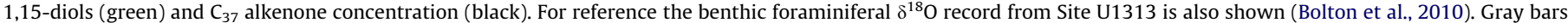
highlight glacial periods. (For interpretation of the references to color in this figure legend, the reader is referred to the web version of this article.)

calculated semi quantitatively by normalizing the peak areas (\%) to the sample with maximum peak area $\mathrm{g}^{-1}$ sediment (sum total peak areas divided by dry wt. of each sample). The LDI-based SST and total relative diol abundance were then compared with reported alkenone-based SST (Naafs et al., 2012) and newly obtained total $\mathrm{C}_{37}$ alkenone concentration, calculated as per Naafs et al. (2010), obtained from the same samples.

\section{Results and discussion}

Of the total of 14 samples, 9 contained sufficient long chain diols to allow LDI-based SST to be determined (Fig. 1). The relative abundance of the long chain diols was highest during glacials (MIS 98 and 96) and co-varied with the concentration of $\mathrm{C}_{37}$ alkenones (Fig. 1). In the other 5 samples, mainly from interglacials, the long chain diols concentration was too low to calculate the LDI. LDIbased SST values are thus restricted mainly to the glacial MIS 96. They vary between 21 and $17{ }^{\circ} \mathrm{C}$ during MIS 96, closely following alkenone-based SST values (Fig. 1). The LDI SST depicts the same glacial cooling as does alkenone-based SST during both MIS 98 and 96 and the subsequent return to interglacial values. Within the limited number of samples, there is no systematic offset between LDI SST and alkenone SST. The results thus indicate that the proposed calibration between the LDI and annual mean SST, based on 162 core top samples from the oceans (Rampen et al., 2012), may also be applicable to the early Pleistocene, when boundary conditions were different from today. Assuming that the alkenone-based SST values are accurate, this indirectly implies that the source organisms, possibly eustigmatophyte algae, were the same during the early Pleistocene as today, or were closely related and had a similar temperature dependence between the LDI and SST.
In addition to the $C_{28} 1,13-$, the $C_{30} 1,13$ - and 1,15-diols, one sample contained significant amounts of the $C_{28: 0}$ and $C_{30: 0} 1,14-$ diols (2.429 Ma). These long chain diols have been reported in marine diatoms of the genus Proboscia and their relative abundance has also been suggested to correlate with growth temperature (Sinninghe Damsté et al., 2003; Rampen et al., 2007, 2009, 2011). However, the temperature obtained for this sample, $29.0^{\circ} \mathrm{C}$ using the 1,14 -diol index, vs. $18.2^{\circ} \mathrm{C}$ (LDI) and $17.6^{\circ} \mathrm{C}$ (alkenones) is unrealistically high for early Pleistocene mid-latitude North Atlantic glacial temperature values. Although based on only one sample, this suggests that at our study site the 1,14-diol palaeothermometer does not result in realistic SST estimates for this time period.

During the glacials of the early Pleistocene, surface water productivity (based on $\mathrm{C}_{37}$ alkenones and dinoflagellate mass accumulation rate) at the study site increased drastically due to the southward migration of the Arctic Front to the mid-latitude North Atlantic (Versteegh et al., 1996; Naafs et al., 2010). It is likely that the elevated concentration of 1,13 and 1,15 diols during glacials in the early Pleistocene is also related to increased surface water productivity, possibly of eustigmatophyte algae. During the interglacials in the early Pleistocene, Site U1313 was at the northern end of the subtropical gyre, characterized by oligotrophic conditions, and the amount of long chain diols in the sediments was very low.

\section{Conclusions}

Using a limited number of sediment samples from IODP Site U1313 in the mid-latitude North Atlantic, we have shown preliminary results that indicate that the LDI may be used to obtain SST estimates for the early Pleistocene (MIS 96) that are similar to those based on other proxies. This suggests potential for this novel paleothermometer for future application to studies comprising 
the entire Quaternary. However, future work involving continuous marine sediment records from multiple locations and covering longer time intervals are needed to validate these results before the LDI can be considered a robust temperature proxy for the Quaternary.

\section{Acknowledgements}

The study used samples and data provided by the Integrated Ocean Drilling Program (IODP). B.D.A.N. acknowledges funding by the Deutsche Forschungsgemeinschaft (DFG) through DFG grant NA 973/1-1. Data supplement can be found online at doi.pangaea.de/10.1594/PANGAEA.780003. We thank S.W. Rampen and an anonymous reviewer for comments.

\section{Associate Editor-J.R. Maxwell}

\section{References}

Bolton, CT, Wilson, PA, Bailey, I, Friedrich, O, Beer, CJ., Becker, J., Baranwal, S Schiebel, R., 2010. Millennial-scale climate variability in the subpolar North Atlantic Ocean during the late Pliocene. Paleoceanography 25, PA4218. http:// dx.doi.org/10.1029/2010PA001951.

Hefter, J., 2008. Analysis of alkenone unsaturation indices with fast gas chromatography/time-of-flight mass spectrometry. Analytical Chemistry 80, 2161-2170. http://dx.doi.org/10.1021/ac702194m.

Locarnini, R.A. Mishonov, A.V., Antonov, J.I., Boyer, T.P., Garcia, H.E., 2006. Volume 1: Temperature. In: Levitus, S. (Ed.), World Ocean Atlas 2005. U.S. Government Printing Office, Washington, D.C., 182 pp.

Morris, R., Brassell, S., 1988. Long-chain alkane diols: biological markers for cyanobacterial contributions to sediments. Lipids 23, 256-258. http:// dx.doi.org/10.1007/bf02535468.

Naafs, B.D.A., Stein, R., Hefter, J., Khèlifi, N., De Schepper, S., Haug, G.H., 2010. Late Pliocene changes in the North Atlantic Current. Earth and Planetary Science Letters 298, 434-442. http://dx.doi.org/10.1016/j.epsl.2010.08.023.

Naafs, B.D.A., Hefter, J., Acton, G., Haug, G.H., Martínez-Garcia, A., Pancost, R., Stein R., 2012. Strengthening of North American dust sources during the late Pliocen (2.7 Ma). Earth and Planetary Science Letters 317-318, 8-19. http://dx.doi.org/ 10.1016/j.epsl.2011.11.026.
Prahl, F.G., Wakeham, S.G., 1987. Calibration of unsaturation patterns in long-chain ketone compositions for palaeotemperature assessment. Nature 330, 367-369. http://dx.doi.org/10.1038/330367a0.

Rampen, S.W., Schouten, S., Wakeham, S.G., Sinninghe Damsté, J.S., 2007. Seasonal and spatial variation in the sources and fluxes of long chain diols and mid-chain hydroxy methyl alkanoates in the Arabian Sea. Organic Geochemistry 38, 165179. http://dx.doi.org/10.1016/j.orggeochem.2006.10.008.

Rampen, S.W., Schouten, S., Schefuß, E., Sinninghe Damsté, J.S., 2009. Impact of temperature on long chain diol and mid-chain hydroxy methyl alkanoate composition in Proboscia diatoms: results from culture and field studies. Organic Geochemistry 40, 1124-1131. http://dx.doi.org/10.1016/ j.orggeochem.2009.08.005.

Rampen, S.W., Schouten, S., Sinninghe Damsté, J.S., 2011. Occurrence of long chain 1,14-diols in Apedinella radians. Organic Geochemistry 42, 572-574. http:// dx.doi.org/10.1016/j.orggeochem.2011.03.009.

Rampen, S.W., Willmott, V., Kim, J.-H., Uliana, E., Mollenhauer, G., Schefuß, E., Sinninghe Damsté, J.S., Schouten, S., 2012. Long chain 1,13- and 1,15-diols as a potential proxy for palaeotemperature reconstruction. Geochimica et Cosmochimica Acta 84, 204-216. http://dx.doi.org/10.1016/j.gca.2012.01.024.

Schouten, S., Hopmans, E.C., Schefuss, E., Sinninghe Damsté, J.S., 2002. Distributional variations in marine crenarchaeotal membrane lipids: a new tool for reconstructing ancient sea water temperatures? Earth and Planetary Science Letters 204, 265-274. http://dx.doi.org/10.1016/S0012-821X(02)00979-2.

Sinninghe Damsté, J.S., Rampen, S., Irene, W., Rijpstra, C., Abbas, B., Muyzer, G., Schouten, S., 2003. A diatomaceous origin for long-chain diols and mid-chain hydroxy methyl alkanoates widely occurring in Quaternary marine sediments: indicators for high-nutrient conditions. Geochimica et Cosmochimica Acta 67, 1339-1348. http://dx.doi.org/10.1016/S0016-7037(02)01225-5.

Versteegh, G.J.M., Brinkhuis, H., Visscher, H., Zonneveld, K.A.F., 1996. The relation between productivity and temperature in the Pliocene North Atlantic at the onset of northern hemisphere glaciation: a palynological study. Global and Planetary Change 11, 155-165. http://dx.doi.org/10.1016/09218181(95)00054-2.

Versteegh, G.J.M., Bosch, H.J., De Leeuw, J.W., 1997. Potential palaeoenvironmental information of $C_{24}$ to $C_{36}$ mid-chain diols, keto-ols and mid-chain hydroxy fatty acids; a critical review. Organic Geochemistry 27, 1-13. http://dx.doi.org/ 10.1016/s0146-6380(97)00063-6.

Volkman, J.K., Barrett, S.M., Dunstan, G.A., Jeffrey, S.W., 1992. $C_{30}-C_{32}$ alkyl diols and unsaturated alcohols in microalgae of the class Eustigmatophyceae. Organic Geochemistry 18, 131-138. http://dx.doi.org/10.1016/0146-6380(92)90150-V.

Yamamoto, M., Ficken, K., Baas, M., Bosch, H.J., de Leeuw, J.W., 1996. Molecular palaeontology of the earliest Danian at Geulhemmerberg (The Netherlands). Geologie en Mijnbouw (Geology and Mining) 75, 255-267. 